\title{
Kelebeğin Rüyası Filmi Üzerinden Tüberküloz ve Heybeliada Sanatoryumu *
}

\author{
Tuberculosis and Heybeliada Sanatorium on the Butterfly's Dream Movie \\ Gülay Halidi', Alper Bulutti, Abdullah Yıldıziii, Ayşe Kurtoğluiv, illknur Genç Kuzucav', Hayati Bicevi, Şekure \\ Handan Akın vii , Serap Şahinoğluviii
}

i Öğretim Görevlisi, Çukurova Üniversitesi Abdi Sütcü Sağlık Hizmetleri Meslek Yüksekokulu, Illk ve Acil Yardım Programı, Doktora Öğrencisi, Çukurova Üniversitesi Sağlık Bilimleri Enstitüsü Tıp Tarihi ve Etik A.D., https://orcid.org/0000-0003-1564-0484

iiDoktora Öğrencisi, Ankara Üniversitesi Sağlık Bilimleri Enstitüsü Tıp Tarihi ve Etik A.D.

Dr., Gülhane Eğitim ve Araştırma Hastanesi, https://orcid.org/0000-0001-7060-7404

iiiiDoktora Öğrencisi AnkaraÜniversitesi Sağlık Bilimleri Enstitüsü Tıp Tarihi ve Etik A.D.

Araş. Gör., Ankara Üniversitesi Tıp Fakültesi Tıp Tarihi ve Etik Anabilim Dalı, https://orcid.org/0000-0001-5135-7200

ivDoktora Öğrencisi, Ankara Üniversitesi Sağlık Bilimleri Enstitüsü Tıp Tarihi ve Etik A.D.

Araş. Gör., Ankara Üniversitesi Tıp Fakültesi Tıp Tarihi ve Etik Anabilim Dalı, https://orcid.org/0000-0001-8622-4547 vDoktora Öğrencisi Ankara Üniversitesi Sağlık Bilimleri Enstitüsü Tıp Tarihi ve Etik A.D. https://orcid.org/0000-0003-4100-4502 viDoktora Öğrencisi, Ankara Üniversitesi Sağlık Bilimleri Enstitüsü Tıp Tarihi ve Etik A.D. Uz. Dr., T.C. Radyo ve Televizyon Üst Kurulu, https://orcid.org/0000-0002-4644-2440 viiDoktora Öğrencisi, Ankara Üniversitesi Sağlık Bilimleri Enstitüsü Tıp Tarihi ve Etik A.D. Hacettepe Üniversitesi Aşı Enstitüsü Sekreteri https://orcid.org/0000-0001-8338-2443

viiProf. Dr., Ankara Üniversitesi Tıp Fakültesi Tıp Tarihi ve Etik Anabilim Dalı, https://orcid.org/0000-0003-4462-2402 Öz

Tüberküloz basili, XIX. yüzyılın sonlarında tanımlanmış olmasına rağmen yüzyıllar boyunca ölümcül bir hastalık olarak sadece tıp tarihinde değil, sanat ve düşün alanına etkileri ile de önemli bir yere sahip olmuştur. Birçok ünlü eserin yaratılmasında hastalık etkilerinin rolü olduğu tartışılagelmektedir. Bu kadar geniş etkileri olan hastalık ülkemizde de bir salgın olarak görülmüş ve yoğunluğu yıllar içinde değişse de tüberküloz mücadelesi günümüzde de devam etmektedir.

Sanat ve sanatçı özelinde farkı yansımaları bulunan tüberküloz, yerli ve yabancı yapımı pek çok filme konu olmuștur. Bu çalıșmada; ikinci dünya savaşının tüm dünyayı yaktığı yıllarda yokluk ve salgınlarla mücadele eden genç Türkiye Cumhuriyetinden bir kesitle, iki genç şairin yaşadığı heyecanların ve aşklarının yanında tüberkülozla mücadelelerini konu eden Kelebeğin Rüyası filmi ele alınmıştır. Bu filmin konusu ve kapsadığı dönem bağlamında hastalık olarak tüberkülozun nasıl algılandığı, bireysel ya da kurumsal tüberküloz mücadelesinin yansımaları ve filmin bu mücadelede ön plana çıkardığı bir kurum olan Heybeliada Sanatoryumu irdelenmiştir.

Mustafa Kemal Atatürk'ün emriyle 1924 yılında 16 yataklı olarak açılan sanatoryum; geçen yıllar içinde yatak kapasitesini arttırmış, tedavi hizmetleri yanında Prof. Dr. Siyami ERSEK gibi birçok hekime uzmanlık eğitimi veren bir eğitim kurumu olmuştur. Zamanın zor şartlarına rağmen hastalar ancak varsıl insanların bulabildiği yiyecekler ile beslenmiş, sanatoryum tedavi hizmetlerinin yanında uzun süren tedaviler boyunca hastalara meslek edinme kursları düzenleyen rehabilitasyon merkezi olarak hizmet vermiştir. Yıllar içinde devlet desteğinden mahrum kalan ve maddi imkansızlıklarla boğuşan sanatoryum 18 Ekim 2009'da çıkan yangın ile yanmış ve bir tarih tamamen kapanmıştır.

Anahtar Kelimeler: Tüberküloz, Sanat, Kelebeğin Rüyası Filmi, Heybeliada Sanatoryumu, Tıp Tarihi

\section{ABSTRACT}

Tuberculosis, though described in late $20^{\text {th }}$ century, has been a focus of interest for centuries not only for history of medicine but in the field of art and philosophy as well. It has been argued that the disease had impact on many famous artworks of well-known artists. Tuberculosis with that widespread effects has also effected Turkey; outbreaks were seen and struggle against tuberculosis is still on.

Tuberculosis, which affects art and artist deeply, is theme of many movies. Kelebeğin Rüyası (Butterfly's Dream), a sample of modern Turkish cinema, deals a story passed in the hard days of Second World War, and focused on two young poets, which experience enthusiasms, loves and tuberculosis. This movie which is handled in this paper, shows early Turkish Rebuplic's struggle against poverties and epidemics. We have studied via this period movie, perception of tuberculosis, personal and institusional fighting agains this disease, and Sanatorium of Heybeliada which is an important part of this fighting.

The opening of Heybeliada Sanatorium dates back to 1924. It was opened with the command of Mustafa Kemal Atatürk with 16 beds, in the meantime enlarged its capacity and began training the doctors such as Prof. Siyami ERSEK and organized occupational courses for long term patients. The treatment was on moral support and being in good conditions with rich rations containing meat, milk and honey. This was a life standard which could only be achieved by wealthy people those times. After 80 's, sanatorium began to lose governmental support. This caused a regression in all services. Finally with the fire on $18^{\text {th }}$ October 2009 , sanatorium was destroyed and a history had ended.

Keywords: Tuberculosis, Art, The Movie Butterfly's Dream, Heybeliada Sanatorium, History of Medicine.

*Lokman Hekim Dergisi, 2019; 9 (3): 376-384

DOI: $10.31020 /$ mutftd.609599

e-ISSN: $1309-8004$

Geliş Tarihi - Received: 22 Ağustos 2019; Kabul Tarihi - Accepted: 2 Eylül 2019

Iletişim - Correspondence Author: Gülay Halidi <gulayhal@gmail.com> 
“Önce öksürüverdim

Öksürüverdim hafiften

Derken ağzımdan kan geldi,

Bir ikindi üstü durup dururken"

Muzaffer Tayyip Uslu

\section{Giriş}

İnsanın varoluşuyla birlikte insanda hastalık yapan tüberküloz, nam-ı diğer verem*, "ince hastalık", "romantik hastalık" olarak da adlandırılmıs, üzerinde çok konuşulup şiirin, romanın, sinemanın ya da kısaca sanatın konusu da olmuştur. Geçen yüzyıllarda çaresizlik, umutsuzluk ve ölümle birlikte anılan bu hastalık, hekim Robert Koch tarafından 1882'de tanımlanıp, etkeni Mycobacterium tuberculosis ya da "Koch Basili" adını alana kadar hakkında çeşitli varsayımlarda bulunuımuştur. ${ }^{1}$

Verem, antitüberküloz ilaçların keşfi, yaşam ve hijyen koşullarındaki görece iyileşme sayesinde yirminci yüzyılın ikinci yarısında dramatik olarak azalmış olsa da süreç içinde ilaçlara karşı gelişen direnç, artan yoksulluk, olumsuz yaşam koşulları nedeniyle hastalık yeniden bir tehdit olarak hissedilmeye başlamıştır. ${ }^{2}$ Insanlık tarihi boyunca sayısız insanın neredeyse herhangi bir ayrıma uğramadan vereme yakalanması, hastalığın uzun sürmesi ve sıklıkla ölümle sonuçlanması onu bir hastalık olmaktan öteye taşımış, bu durum aynı zamanda toplumsal kültür ve kolektif bilinç üzerinde kendine özgü farklı bir etki yaratmıştır.

Tarihsel bir perspektiften bakıldığında tüberküloz, hem hastalık olarak tıbbın geçmişinde hem de toplumsal bağlamda yankılar uyandırmış medikososyal bir olgudur. Hastalık ve toplum ilişkisi özelinde önemli yere sahip olan tüberkülozun, dikkate değer biçimde sanatçılarda ve farklı dallardaki sanat eserlerinde izler bıraktığını söylemek olanaklıdır. Hastalığın anlaşılmasında-yorumlanmasında ve hastalıkla olan mücadelenin yürütülmesinde başat yaklaşımlardan biri holistik bakış açısıdır. Bu anlayış mevcut diyagnostik-terapötik tıbbi olanakların yanı sıra değişen doğa koşulları, izlenen politikalar, bireysel-toplumsal algılar ve eylemler, tıbbi yaklaşımların evrimi gibi bir çerçevede hastalığın ele alınmasını gerektirir. Dolayısıyla bir olgu olarak hastalığı anlamanın ve bağlamına oturtmanın yollarından biri de, hastalığın bireysel veya toplumsal yansımadaki izlerini sürebilmekten, bu çerçevede sanatçıları ya da sanat eserlerini irdelemekten geçmektedir.

"Kelebeğin Rüyası Filmi" bu bağlamda irdelenmeye değer niteliktedir. Film bir yandan Rüştü Onur ve Muzaffer Tayyip Uslu adlı iki genç şairin erken Cumhuriyet döneminde geçen yaşam serüvenini sunmakta diğer yandan bir hastalık olarak tüberkülozu ele almaktadır. ${ }^{3}$ Cumhuriyet rejimine geçen ve kurucu liderini kaybedişinin hemen ardından bir dünya savaşıyla yüzleşmek durumunda kalan genç Türkiye'deki sosyal, kültürel, ekonomik, politik koşulları yansıtmaktadır. ${ }^{3}$ Filmin kimi kesitlerinde 1939 yılında kabul edilen Milli Müdafaa Mükellefiyeti ve 1940 yılında kabul edilen Milli Korunma Kanunları'nın uygulamalarına yer verilmekte ${ }^{4,5}$; iş mükellefiyetine tabi mahkumların ve köylülerin maden ocağında çalıştırılması gösterilmektedir. ${ }^{3}$ Bir döneme özgü unsurlara tanıklık etme, bir yandan bu durumu yansıtan "Vatan Borcu Çalışma ile Ödenir" içerikli bir duvar yazısı, diğer yandan kadın-erkek ilişkileri, kılık-kıyafet ve dans etme görüntüleri üzerinden verilmektedir. ${ }^{3}$ Cumhuriyet tıp tarihi perspektifinden bakıldığında ise film, tüberkülozun iki genç şairin yaşamı üzerindeki etkisi, tüberkülozun ve onunla mücadelenin bireyselkurumsal-toplumsal ilişkideki yansımaları dönemin kendine özgü bağlamı ve koşulları içerisine yerleştirilerek holistik bir biçimde aktarılmaktadır.

Belli bir dönemin ve coğrafyanın tıp tarihini anlamanın yankı uyandıran münferit bir konu, olgu ya da eser özelinde olanaklı olabileceği göz önünde bulundurulduğunda, Kelebeğin Rüyası filmi bu amaca hizmet eder niteliktedir. Bu bağlamda kaleme alınan makalede, filmin izlenerek tüberküloz ve tüberkülozla mücadelenin sosyal, kültürel, ekonomik, politik, tıbbi koşullar perspektifinden bireysel ve kurumsal yansımaları irdelenmiş, filmin ilişkili sekansları değerlendirilerek bunlara yer verilmiştir. Bir başka deyişle çalışmanın

${ }^{*}$ Her ne kadar hastalık etkenine dayanarak tıpta, tüberküloz adlandırılması yapılsa da Türkçede verem sözcüğü kullanılmaya devam etmiştir. Bu bağlamda "tüberküloz" ve "verem” sıklıkla birbiri yerine kullanılmış hatta hastalıkla ilgili dispanser ve dernek adlarında "verem” ifadesine yer verilmiştir. Hastalığı tıbbi boyutunun ötesinde ele aldığımız bu yazıda kaçınılmaz olarak hem verem hem de tüberküloz birbirini kapsar biçimde kullanılmıştır. 
amacı film ve tamamlayıcı kaynaklar üzerinden tüberkülozun medikososyal tarihçesine bir pencere açmak; ondan bir kesit aktarmaktır. Çalışmanın hazırlanmasında izlenen yöntem, ilk aşamada filmi ayrı ayrı izleyip kişisel değerlendirmelerini kaleme alan yazarların ikinci aşamada bir araya gelerek konuyu tartışması ve bu tartışmanın ışığında metni biçimlendirmesidir.

Tüberküloz halk sağıı̆ı sorunu olmanın yanı sıra madenciler gibi kapalı ve havasız ortamda çalışan kişiler için meslek hastalığı değilse bile riski yükselmiş bir sorun olarak da değerlendirilebilir. Filmin başkahramanları madende çalışmamakla birlikte tüberküloz ile maden şehri Zonguldak'ın gündemde bir araya gelişi bu hususu çağrıştırmaktadır. Bununla birlikte filmde yukarıda anılan kanunların uygulamalarının ya da onlara tabi olanların, tüberküloz olgusuyla ilişkilendirilmemiş ve sadece dönemin kendine özgü koşullar içerisinde bağlantısı kurularak aktarılmıştır. Bu nedenle makalemizdeki tüberkülozla ve tıp tarihiyle ilgili sekanslar arasında bunlara yer verilmemiştir.

Tüberkülozun sağlık ve tıpla ilişkisinin ötesinde birey ve toplum yaşamı üzerindeki tesirlerini dile getirmeye çalışan bu makale, birbiriyle bağlantılı ve birbirini bütünleyen üç başlıktan oluşmuştur. Illkinde sanat ile verem ilişkisi genel olarak veremli sanatçılar ve verem temasını işleyen sanat eserleri kapsamında ele alınmıştır. İkinci başlık çok yakın tarihli ilginç bir sinematografik çalışma olan Kelebeğin Rüyası filmidir. Tüberkülozun, öyküye arka plan oluşturduğu bu film, hastalığın edebiyatla ilişkisi, toplumsal etkileri ve hastalığın dönemsel koşullarını anlamamızı da kolaylaştırmaktadır. Son ve üçüncü başlıkta ise filmin tıp tarihiyle bağlantılı kimi sahnelerine mekan olan Heybeliada Sanatoryumu’nun hüzünlü öyküsü filmle ilişkilendirilerek aktarılmaktadır.

\section{Sanatta ve Sanatçıda Tüberküloz}

Tüberküloz, tıp tarihinde olduğu kadar sanat ve edebiyat tarihi içerisinde de özel bir yere sahip olmuştur. Tanısal olarak hastalığın nedeninin henüz bilinmediği dönemlerde, veremin sanatçının yeteneğini etkilediği düşünülmüştür. Kuşkusuz bunda bazı sanatçı ve ünlü kişilerin hastalıktan çekmiş olduğu acı ve ıstırabın da payı bulunmaktadır. Söz konusu dönemde öne sürülen varsayımlardan biri sanatçıların hafif ateş ve toksemi tablosundayken dünyayı ve yaşantıları daha açık ve net olarak görüp eserlerini oluşturduklarıdır. Bir başka düşünce ise bu kişilerin aslında hastalığa bağı fiziksel olarak zayıf düştükleri ve bu nedenle sanatı seçme eğiliminde oldukları yönündedir. ${ }^{6}$

Hasta Çocuk ve Çığlık gibi ünlü tabloların sahibi olan Edward Munch başta olmak üzere çok sayıda ressam tüberkülozdan etkilenmiştir. ${ }^{7}$ Ayrıca resim alanında Jean-Antoine Watteau, Elizabeth Sidal, Maria Bashkirtseff, Aubrey Beardsley ve Amedeos Modigliani gibi ünlü ressamlar bu hastalığa yakalandıktan sonra hastalıkla olan ilişkileri eserlerinin kapsam ve içeriğini etkilediği düşünülmektedir. ${ }^{6}$ Sanatın farklı alanlarındaki pek çok sanatçı tüberkülozdan etkilenerek eserlerinde bu hastalık ile bir biçimde bağ kurmuşlardır. Müzik alanında Purcell, Chopin, Ethelbert Nevin gibi sanatçılar bunun birer örneğidir. Felsefe ve düşünce dünyasında tüberkülozdan etkilenen çok sayıda felsefeci arasında Spinoza, Descartes, Rousseau, Butler, Locke, Kant ve Voltaire vereme yakalanıp, onunla mücadele etmişlerdir. ${ }^{8}$

Edebiyat alanından hastalığa yakalanan ya da kendisini hasta olarak değerlendirenler arasında Jane Austen, Katherine Mansfield, R. L. Stevenson, D. H. Lawrence, L.I. Powys, Mrs. Henry Wood, Charles Kingsley, George Orwell, Edgar Allan Poe, Thoreau, Whittier, Washington Irving, Chekov, Schiller, Balzac ve Moliere'den söz edilebilir. ${ }^{8}$

Yazarların yanı sıra edebiyat eserlerinde veremli hastaları görmek mümkündür. Dostoyevski'nin ünlü eseri Suç ve Ceza'da, Katerine Ivanovna böyle bir karakter olarak karşımıza çıkarken, Victor Hugo'nun büyük beğeni kazanan eseri Sefiller'de, Fantin karakterini görürüz. ${ }^{9}$

Veremin içsel yaratıcılığı tetiklediği ve edebi yeteneği arttırdığı hatta bazen daha da ileri gidilerek, hastalığın sükunet dönemlerinde veremli yazarların yazım kalitesinin düştüğü, eser sayısının azaldığına bile dikkat çekilmektedir. Örneğin Define Adası adlı eserin yazarı, R. L. Stevenson, hastalık bulgularının kendisinde olumlu bir etkiye yol açtığına bile inanmaktadır. Yazar, toksemide ve ateşli olduğu dönemlerde daha fazla eser vermiştir. Ancak bu durumun yazarın iddia ettiği veya inandığı üzere hastalığın yaratıcılığını tetiklemesinden mi ya da yazarın eserini tamamlayamama korkusunun eşlik etmesinden mi kaynaklandığı bilinememektedir. ${ }^{8}$ 
Edebiyat alanında özellikle şair ve şiirin veremle olan ilişkisinin daha dikkat çekici olduğu söylenebilir. Hastalığa yakalanan ya da hastalığı içselleştiren şairler arasında Oldham, Gay, Littleton, Percy Bysshe Shelley, Thomas Hood, Gray, E. B. Browning, Symonds, Thompson, Flecker, W. E. Henley, R. L. Stevenson, Dylan Thomas gibi adlar sayılabilir. Dylan Thomas Thompson modern dönem şairlerindendir, tüberkülozlu olmadığı halde kendisini öyle tanıttığı düşünülmektedir. Ölüm teması şairin neredeyse tüm dizelerinde karşımıza çıkar. Thomas şairin erken ölmesi gerektiğini düşünür ve kendisine zarar verecek riskli bir yaşam sürer. ${ }^{8}$ Bu konudaki bir başka ilginç değerlendirme ise edebiyatçıların ve sanatçıların ilk yıllarında yoksulluğun ve parasızlığın oldukça olağan bir durum olarak görülmesidir. Ancak bu yaşam koşullarına sahip edebiyatçıların ve sanatçıların hastalık karşısındaki direnci düşmektedir. Ayrıca eş zamanlı alkol ve ilaç kullanımı tüberküloza yakalanmayı kolaylaştırırken hastalığın yaygın görülmesi doğal bir sonuçtur. ${ }^{8}$

Verem, divan şiirinde de işlenmiş bir konudur. Divan şiirinde verem devası olmayan, ölümcül bir hastalık olarak yer bulmuştur. Şairlere göre hastalık göğüs ve akciğerdedir. Aşık şairler dertlerinin büyüklüğü ile verem hastalığına yakalanmaları arasında bağ kurarlar. Onlara göre aşk acısı veremin önemli bir sebebidir. Nefret, kızgınlık ve kin gibi duygular da vereme sebep olmaktadır. Divan şiirinin önemli bir öğesi olan metaforik anlatımlar içinde sevgili, doktora benzetilirken şair de verem hastası olarak nitelendirilmiştir. ${ }^{10}$

Görece yeni bir sanat alanı olan sinemada tüberkülozu görmek mümkündür. Örneğin oskültasyonun gelişimini ve tüberkülozla mücadeleyi anlatan Docteur Laennec (1949) bu filmlerden biridir. Bir başka film ise tüberküloz ile mücadelede idealist bir karakteri konu edinen The Citadel' dir (1939). Bunların dışında başka filmlerde de tüberkülozlu karakterleri görmek mümkündür. ${ }^{11}$ Zaman içinde özellikle delilik ve AIDS konulu filmler sinemada daha sık karşımıza çıksa da genel olarak verem olgusunun daha az yer aldığı söylenebilir. Ancak son dönemde verem konusunda duyarlılık ve farkındalık yaratılması amacıyla doğrudan hastalığın işlendiği senaryolar, sağlığa ilişkin film festivallerinde izleyiciyle buluşmuştur. ${ }^{12}$

Türk sinemasında tüberküloz, edebiyat ve şiirdeki yansımalarında olduğu gibi melodramik bir görünüm biçiminde film karakterlerine yansıtılmışıı. Yani tüberkülozun kendisi filmin odağında olmasa da "tüberkülozlu karakterler" film karelerinde görünür olmuştur. Bu bağlamda 1955 yapımı Son Beste filminin kadın karakteri, verem bağlamında estetize edilmiş bir figür olarak sunulur. Hıçkırık (1965), Beyaz Güller (1970) ve Boş Çerçeve (1969) gibi filmlerde de benzer karakterler karşımıza çıkar. Filmlerde tüberkülozun, özellikle kadın kahramanlar üzerinden, çeşitli duyguların ve yaşanmamışıkların melankolik bir dışavurumu olarak imgelendiği ve ölüme estetik bir anlam katarken resmedildiği ifade edilmektedir. ${ }^{13}$

Çalışmamızın ana eksenini oluşturan Kelebeğin Rüyası filminde şiir ve şairler önemli bir yer tutmaktadır. Film boyunca üç şairin şiirleri ve güzel sözleri dikkat çekmektedir. Şairlerin ölümsüzlüğe ulaşmak için uzun bir yaşama intiyaç duymadıkları, "birkaç satırın şairin ölümsüzlüğe ulaşmasına yeteceği" üzerinde durulmuştur.

\section{Tüberkülozun Kelebeğin Rüyası Filmindeki Yansımaları}

Salgın hastalıkların yayılmasında ve ölümcül sonuçlara yol açmasında önemli faktörlerden biri de savaşlardır. Cephede beslenme, barınma ve temizlikle ilgili olumsuz koşullar çeşitli hastalıklara zemin hazırlamakta, büyük kitlelerin bir arada bulunması hastalığa yakalanma olasılığını artırmaktadır. Savaşın neden olduğu her türlü sınırlı olanak veya yokluk hem savaş esnasında hem de sonrasında hastalıkların tedavisini ve kontrolünü güçleştirmekte, olumsuz durumlar ortaya çıkarmaktadır. İkinci dünya savaşı ateşinin tüm dünyayı yaktığı günlerde genç Türkiye Cumhuriyeti de yokluklarla ve salgın hastalıklarla mücadele etmektedir. Bu dönemden bir kesit veren Kelebeğin Rüyası filmi tıp tarihi açısından hem tüberkülozla ilgili ana teması hem de ana mekanı olan Heybeliada Sanatoryumu ile karşımıza çıkmaktadır.

Yılmaz Erdoğan'ın hem yazdığı hem yönettiği hem de Behçet Necatigil'i canlandırdığı Kelebeğin Rüyası adlı film, 2013'te vizyona girmiştir. ${ }^{3}$ Söz konusu film 1941 yazında, Türkiye'de cumhuriyetin erken dönemlerinde, dünyada ise ikinci dünya savaşı yıllarında geçmektedir. ${ }^{3,14}$ Film bu dönemi kendi bakış açısıyla ele alarak Mert Fırat ve Kıvanç Tatlıtuğ tarafından canlandırılan, iki genç şair Rüştü Onur ve Muzaffer Tayyip Uslu'nun yaşamlarını anlatır. ${ }^{3,14}$ Zonguldak'ta yaşayan ve bir yandan memurluk yapan öte yandan şiir yazan bu iki genç şairin en büyük emeli, edebiyat alanındaki önemli bir dergide şiirlerinin yayımlanmaya başlaması ve bunun sürekli hale gelmesidir., ${ }^{3,14}$ Şiir yazma konusunda hem kendi aralarında 
hem de gıpta ettikleri hocaları Behçet Necatigil ile tatlı bir yarış içindedirler. ${ }^{3,14}$ Kuşkusuz bu durum, şiirin onların yaşamındaki önemli bir odak olduğunun göstergesi olarak kabul edilebilir.

Kelebeğin Rüyası filminin şiir-aşk-tüberküloz üçgeninde geçtiğini söylemek olanaklıdır. Bu eşkenar bir üçgendir ve ele alınan üç tema merkeze eşit mesafededir. Filmin başkahramanları olan iki genç şair yaşamları tüberkülozla kesişmiş birer hastadır. ${ }^{3,14}$ Doğal olarak tüberkülozun 1940 'lı yıllardaki tanı ve tedavisine ilişkin ipuçları filmde bu iki karakter aracılığıyla seyirciye sunulur. ${ }^{3,14}$ Tüberküloz hastalığının konu olduğu birçok Türk filminden farklı olarak, Kelebeğin Rüyası'nda hastalık, aşkına karşılık bulamamanın veya kavuşamamanın melankolik bir sonucu olarak değil, hayatın akışının içerisine yerleşmiş bir unsur, dönemin sıkıntılı sosyal koşullarının olağan bir sonucu biçiminde işlenmektedir.

Filmde tüberkülozun nasıl bir hastalık olduğu, nasıl ilerlediği izleyiciye betimlenmekte; ayrıca yoksullukları da vurgulanan iki genç şairin oldukça zayıf ve hastalıklı halleri gösterilmektedir. ${ }^{3}$ Tüberkülozla ilgili ön plana çıkan mesaj, hastalığın çoğunlukla acı kayıplarla sonuçlandığı dolayısıyla ölümcül seyrettiğidir. ${ }^{3,14}$ Bu mesajın ön plana çıkmasında etkili olan unsurun şiir konusunda tutkulu ve üretken şairlerin, daha nice şiirler yazıp edebiyat tarihindeki yerini alamadan erken yaşlarda tüberkülozdan hayatlarını kaybetmeleri olduğu yorumu yapılabilir. Burada bir parantez açarak iki genç şairin şiir konusundaki yeteneklerinin, makalenin tüberkülozsanat-sanatçı ilişkisini ele alan bölümünde yer verilen, tüberkülozun içsel yaratıcılığı tetiklemesine ve edebi yeteneği geliştirmesine ilişkin varsayım bağlamında işlenmediğini söylemek olanaklıdır. Onur'un karısının ölümünden sonra Uslu ile birlikte bir odaya kapandıkları sahnede, ikilinin odanın dört duvarına şiirler yazmasının ${ }^{3,14}$ tüberküloz hastalığının yaratıcılığa olan katkısının değil yaşanılan kayıp acının bir göstergesi olması daha kuvvetle muhtemeldir. Ancak yine de aynı sahnenin sonunda Onur'un kan tükürerek ölmesi bu bakımdan düşündürücüdür. Filmde tüberküloz çoğu sanat eserindeki betimlemeye benzer şekilde öksürürken "kan tükürme" yle sembolize edilir. Kan tükürmenin, ilerleyici bir biçimde kötüye gidişi ve dolayısıyla iyileşememeyi ifade eden bir metafor olduğu söylenebilir.

Filmde, hastalık olarak tüberkülozun toplumda nasıl algılandığına ve yorumlandığına da yer verilmektedir. $\mathrm{Bu}$ bağlamda ilk unsur tüberkülozun bulaş yolunun ve bulaşma korkusuyla karışık izolasyon tedbirleri alınmasının işlendiği sahnelerdir. Bu sahnelerden birinde tanışmak üzere olduğu bir genç kadın, öksürmeye başlaması üzere Onur'un elini sıkmamaktadır. ${ }^{3,14}$ Onur'un Amele Birliği Hastanesinin tüberküloz koğuşunda yattığı sahnede, Uslu'nun arkadaşının elini sıkmayan bu kadına serzenişi ve Onur'un "korktu herkes gibi" değerlendirmesi yer almaktadır. ${ }^{3,14}$ Uslu'nun söz konusu kadınla birlikte yürüdüğü demiryolu sahnesinde, "aslında tokalaşınca verem bulaşmaz" demesi de izleyiciye bilgi aktarımı niteliğindedir. ${ }^{3,14}$ işlenen ikinci unsur ise tüberkülozun ölümcül seyretmesi karşısındaki çaresizliktir. Tüberküloz halk tarafından acı kayıplarla sonuçlanan bir hastalık olarak deneyimlenmiştir. Bununla ilişkili sahnelerden birinde belediye başkanı, sevdiği insanları bu hastalıktan kaybettiğini söyleyerek kızıyla iki genç şairin arkadaşlığını korkuyla karşıladığını ve kızını da bu hastalıktan kaybetmek istemediğini dile getirir. ${ }^{3,14}$ Tüberküloz karşısında çaresiz kalmanın vurgulandığı bir diğer sahnede bu durum, Uslu’nun evde bitap düştüğg̈ ve yatakta kan tükürdüğü sırada babasının ve hocası Necatigil'in bakışmaları üzerinden hüzünlü bir biçimde aktarılır. ${ }^{3,14}$ Tüberkülozdan ölüm endişesinin işlendiği bir diğer sahnede, Heybeliada Sanatoryumu'nda hayatını kaybeden birinin bedeni sedye üzerinde bahçeden geçirilirken hemşireler bu sahneye hüzünlü gözlerle bakakalan hastaları balkondan uzaklaştırmaya çalışır. ${ }^{3,14}$

Onur'un ve Uslu'nun yaşadığı döneme özgü çok temel bir nokta tüberkülozu tedavi olanaklarının oldukça sınırı olmasıdır. Bu sınırlılık hem sanatoryumların sayıca az olmasından hem de ilaçla tedavi şansının henüz bulunmamasıdır. İki genç şairin tüberkülozla olan mücadelesine tanık olduğumuz filmde, tıbbi destek almalarını sağlama konusunda çaba gösteren en önemli ve belki de yegane kişinin hocaları Necatigil olduğu işlenmektedir. ${ }^{3,14}$ Bu bağlamda tüberkülozun tedavi olanaklarına erişebilmenin zorluğu Necatigil'in yoğun ve ısrarcı çabasında görünür hale gelmektedir. ${ }^{3,14}$ Necatigil'in çabasının etkili olmasıyla iki genç şairin tüberkülozla mücadelede yolları Heybeliada Sanatoryumu'yla kesişir.

\section{Kan Tüküren Prens Adası: Heybeliada Sanatoryumu}

Makalenin bu başlığı altında Kelebeğin Rüyası filmine ve sahnelerine konu olan Heybeliada Sanatoryumu anlatılacaktır. Ancak burada Heybeliada Sanatoryumu'nun tarihinin sınırı aktarımı, belli kesitler üzerinden 
ifade edilecektir. Heybeliada Sanatoryumu, önce kuruluş aşaması bağlamında ele alınacak sonra filmin sanatoryuma ilişkin mesajları irdelenecek ve tüberküloz mücadelesinde önemli bir yere sahip ve sınırlı olanaklarla ilerleme kaydeden sanatoryumun, kurumsal süreksizliğin bir örneği olarak da görülüp, kapanmasına yer verilecektir.

Kelebeğin Rüyası filminin başkarakterleri olan Rüştü Onur ve Muzaffer Tayyip Uslu erken cumhuriyet döneminin yaygın hastalıklarından biri olan tüberküloza yakalanmıştır. ${ }^{3,14}$ iki genç şairin hastalıkla mücadelesine yer veren filmin bu bağlamdaki önemli sekansları, Heybeliada Sanatoryumu'nda geçmektedir. ${ }^{3,14}$ Filmin bu sekanslarında mekanı oluşturan Heybeliada Sanatoryumu, dönemin sağlık politikaları bağlamında tüberküloz hastalığıyla mücadele yöntemlerinin-yaklaşımlarının kurumsalorganizasyonel bir figürü olarak işlenmektedir. Film tüberküloza yakalanmanın iki genç şairin yaşamını dramatik bir biçimde etkilemesini konu edinmenin yanı sıra tüberküloz mücadelesinde Heybeliada Sanatoryumu'na yer vermesi, dönemin sağlık politikalarını gerçeğe yakın bir kurguyla ve arka planla seyirciye sunması bakımından da dikkate değer niteliktedir.

Sıhhat ve Iç̧timai Muavenet Vekaleti (Sağlık ve Sosyal Yardım Bakanlığı) 1924'te Heybeliada Çamlimanı́nın doğusundaki Yeşilburun'da yer alan ve Muhacirin İdaresinin kullandığı binada bir sanatoryum açılmasına karar vermiştir. ${ }^{15,16}$ Sanatoryumun kurulması işi, ilk olarak tüberküloz alanında çalışmaları bulunan ve bu bağlamda ün kazanmış Dr. Reşat Rıza'ya verilmiştir. ${ }^{15}$ Dr. Reşat Rıza, sanatoryumun açılmasına ayrılan bütçenin azığına yönelik itirazını, sanatoryumun uygun-istenir koşullarda olamayacağı endişesini ve sanatoryumun Şişli'de kurulması yönündeki önerisini dile getirmiştir. ${ }^{15}$ Birinci Dünya Savaşı'nın etkilerini taşıyan cumhuriyetin erken dönemindeki maddi olanakların sınırlı olması nedeniyle önerisi kabul edilmeyen Dr. Reşat Rıza görevden çekilmiş, dönemin bakanı Dr. Refik Saydam Heybeliada'da sanatoryum kurulması görevini, İntaniye Hastanesi başhekimi olan Prof. Dr. Server Kamil'e vermiştir. ${ }^{15,17}$ Açılacak Heybeliada Sanatoryumu'nun başhekim vekili olarak atanan Prof. Dr. Server Kamil ile sanatoryumun uzman doktoru olarak görevlendirilen eski öğrencisi Dr. Tevfik İsmail Gökçe, 15 Ağustos 1924'te binayı Muhacirin İdaresi'nden teslim almıştır. ${ }^{15}$

Heybeliada Sanatoryumu olması planlanan bina, Birinci Dünya Savaşı sırasında Harbiye Mektebi öğrencilerine nekahethane olarak kullanılması için okulun müdürü Vehip Bey tarafından inşa ettirilmiştir. ${ }^{15,16}$ Bina sonra "Bahriye Mızıka Mektebi"nin çalışmaları için kullanılmış, daha sonra Birinci Dünya Savaşı sırasında esir alınan İngiliz generali Townshend'e bir süreliğine ikametgah olarak tahsis edilmiştir. ${ }^{15,18}$ Harbiye Nezareti Sıhhiye Dairesi tarafından görevlendirilen Dr. Fevzi (Özet), binanın askeri sanatoryum yapılmasını öngörmüş ancak göçmenler arasında tüberkülozun yayılması nedeniyle bina Muhacirin Idaresi'ne devredilmiş, muhacir tüberküloz hastalarının nekahethanesi olmuştur. ${ }^{15,16}$ Cumhuriyetin ilk devlet sanatoryumu olan Heybeliada Sanatoryumu, Çamlimanı'nın 3850 m'lik Yeşilburun kısmında on altı yataklı bir tesis olarak 1 Kasım 1924'te açılmıştır. ${ }^{15}$ iki katlı binanın üst katı, her birinde sekiz yatak bulunan koğuşlar halinde kadınlara ve erkeklere tahsis edilmiş, alt katı ise idareye ve memurlara ayrılmıştır. ${ }^{15}$ Heybeliada Sanatoryumu'nun ilk başhekimi ve kurucusu olan Prof. Dr. Server Kamil, İntaniye Hastanesi başhekimliğini sürdürmesi nedeniyle on ay sonra bu görevi bırakmış, onun yerine Uzm. Dr. Tevfik İsmail Gökçe atanmıştır. ${ }^{15,16}$ Gökçe, Heybeliada Sanatoryumu başhekimliği görevini emekli olduğu 1955 yılına kadar sürdürmüştür. ${ }^{15}$

Kelebeğin Rüyası filminin Muzaffer Tayyip Uslu'nun ve hocası Behçet Necatigil'in Karadeniz'den İstanbul'a gemi yolculuğuyla ilgili sahnesinde, radyo spikeri Pearl Harbour saldırısını duyurmaktadır. ${ }^{3,14}$ Böylelikle yolculuğun Aralık 1941'de gerçekleştiğinin ipucu izleyiciye aktarılmaktadır. Bu ipucundan yola çıkarak Heybeliada'da geçen sekansta, Behçet Necatigil'in konuştuğu ve iki genç şairin sanatoryumdaki tedavi sürecinde başhekimlik görevini sürdüren kişinin Dr. Tevfik İsmail Gökçe olduğu anlaşılmakta, bu rol oyuncu Engin Şenkan tarafından canlandırılmaktadır. ${ }^{3}$

Heybeliada Sanatoryumu'nun, bir yandan devralınan bina içerisinde ve çevresinde değişikliklere gidilmesi diğer yandan çevresinde bulunan arazilerin istimlak edilmesiyle fiziki kapasitesi genişletilmiş; 1924 yılında on altı olan yatak sayısı 1954 yılının sonunda sanatoryumda beş yüz yirmi, rehabilitasyon merkezinde altmış, rehabilitasyon yardımcı hemşire okulunda elli olmak üzere altı yüz otuz yatağa çıkarıımıştır. ${ }^{15}$ Hizmet kapasitesi de fiziki olanakların artışına paralel gelişme göstermiş ve geniş bir yelpazeye yayılmıştır. Bu 
bağlamda bir yandan tanılamaya yönelik olarak tıbbi görüntüleme, bakteriyolojik ve patolojik inceleme, respiratuar fonksiyon testleri yapılmıştır. Diğer yandan sanatoryum bünyesinde tedaviye yönelik olarak pnömotoraks, pnömoperituvan, ekstraplöral pnömotoraks ensüflasyonları gibi müdahalelerin yapıldığı kollaps ünitesi; brit seksiyonunu, kavern drenajını ve kavernostomiyi gerçekleştiren diğer medikal servisler; toraks şirürjisi kliniği; diş ve KBB gibi destek servisleri bulunmaktadır. ${ }^{15}$

Kelebeğin Rüyası filminin konu edindiği dönem, Heybeliada Sanatoryumu'nun kapasitesini hem fiziksel hem de işlevsel yönden artırdığı döneme tekabül etmektedir. ${ }^{3,15}$ Ayrıca filmin geçtiği dönem düşünüldüğünde İstanbul'da biri özel işletme ve Heybeliada Sanatoryumu'yla birlikte dördü devlet kurumu olan toplam beş sanatoryum bulunmaktadır. ${ }^{17}$ Film ele aldığı dönemi, tüberküloz hastalığının yaygın olduğuna ve sanatoryumda tedavi görme olanağının sınırlı bulunduğuna ilişkin sekansıyla betimlemektedir. ${ }^{3,14} \mathrm{Bu}$ bağlamda sanatoryumların tüberkülozlu hasta sayısına yetmediği; sanatoryuma girmek için hastaların sıralarının gelmesini bekledikleri, filmin ilgili sekansında gözler önüne serilmektedir. ${ }^{3,14}$ Bu sekansa ilişkin sahnelerden biri, tüberkülozun Rüştü Onur'u zayıf düşürdüğünü ve tıbbi destek almaya muhtaç hale getirdiğini işaret etmektedir. ${ }^{3,14}$ Bir diğer sahneden ise, Behçet Necatigil'in Rüştü Onur'un tedavisi için devreye girdiği anlaşılmaktadır. Necatigil'in Muzaffer Tayyip Uslu'ya söyledikleri Rüştü Onur'un tıbbi destek alması konusunda pek çok kişiyle yazıştığının işaretini vermektedir. ${ }^{3,14}$ Necatigil, bu yazışmalar sonucu yardım alacağını pek de ummadığı biri aracılığıyla Rüştü Onur'un Heybeliada Sanatoryumu'na kabulünü sağlamıştır. ${ }^{3,14}$

Bir başka sahnede bu konu, Onur'un Uslu'ya Heybeliada Sanatoryumu'ndan yazdığı mektup üzerinden işlenmektedir. ${ }^{3,14}$ Onur, Uslu'nun sanatoryuma kabul edilmesi için konuştuğunu ancak hasta kabulünün sırayla gerçekleştiğini yazmaktadır. ${ }^{3,14}$ Sanatoryumda tedaviye kabul edilmenin zorlu koşullarının aktarımı, Uslu'nun tüberkülozdan yattığı ve kan tükürdüğü ev sahnesi ile başlamakta, hocası Necatigil ile Zonguldak'tan Heybeliada'ya uzanan yolculuk ve varış, sanatoryumun kapısından reddedilme, hocasıyla yürürlerken başhekim Gökçe'yle karşılaşma sahneleri ile devam etmektedir. ${ }^{3,14}$ Sanatoryuma kabul edilmenin meşakkatli yolunun tekrar tasvir edildiği bir sahne de Gökçe ve Necatigil arasında geçen diyalogdur. ${ }^{3,14}$ Bu diyalogda hastaların sanatoryuma sırayla kabul edildikleri tekrar gündeme getirilmekte; Necatigil, başhekimin Uslu'yu sanatoryuma kabul etmesi için ısrar etmektedir. ${ }^{3,14}$

Tüberküloz hastalarının bakım ve tedavi ihtiyacını karşılamak için yatak kapasitesini artıran Heybeliada Sanatoryumu; hem "bakım ve tedavi hizmetleri", hem birçok hekime uzmanlık eğitimi veren ve rehabilitasyon merkezi bünyesinde bulunan okulda yardımcı hemşire yetiştiren bir "eğitim kurumu", hem de uzun süren tedavileri boyunca hastalara meslek edinme kursları düzenleyen bir "rehabilitasyon merkezi" olarak bir hastaneden çok daha fazlası olmuştur. ${ }^{15}$ Bir yandan hastaları moral olarak desteklemek için muntazam aralıklarla konser verilmiş ya da sinema seansı yapılmış, öte yandan hastaların beslenmesine özen gösterilerek günde dört öğün olarak verilen yemekler et, süt ve bal ilave edilerek zenginleştirilmiştir. ${ }^{15}$

Kelebeğin Rüyası filminin, cumhuriyetin erken dönemindeki gerçek yaşam öykülerinden yola çıkan kurgusu sinematografinin başarılı bir örneği olarak karşımıza çıkmaktadır. Bu başarıyı sağlayan unsurlar olarak filmin akıcı kurgusu, gerçekçi yaklaşımı, yalın anlatım dili, Heybeliada Sanatoryumu'nun terkedilmiş binasını düzenleyerek gerçek mekanında çekilmesi sıralanabilir. Kelebeğin Rüyası filmi, izleyiciye Heybeliada Sanatoryumu'nu doğrudan göstermenin yanı sıra yukarıda sıralanan kimi işlevlerine ve işleyişine ilişkin mesajlar da aktarmaktadır. Filmde hastalar üç ay ya da daha uzun süre sanatoryumda kalmakta, tedavi süreci uygun barınma, beslenme, temizlik koşullarının sağlanmasının yanı sıra bir hijiyenodiyetetik tedavi türü olan açık hava kürü ve sınırlı temas izolasyonu yolu ile gerçekleşmektedir. ${ }^{3,14}$

Filmin tüberküloz ve beslenme arasında ilişkiye dikkat çektiği sahnesinde, Onur'un Uslu’ya mektubunda "tüm meselenin üç öğün yemek" olduğunu yazması yer almaktadır. ${ }^{3,14}$ Barınma ve izolasyonla ilişkilendirilebilecek sahnelerine örnek olarak, Uslu'nun sanatoryumda geçen üç ayın kimsenin iyileşmesi için yeterli olmadığını vurgulaması ve aralıklı olarak tekrarlanan sanatoryumun "sarılmak yok" mottosu gösterilebilir. ${ }^{3,14}$ Sanatoryumun işleyişiyle ilgili sahnelerde ise Onur'un ve Uslu'nun sanatoryuma girmeyi bekledikleri vurgulanmakta; Necatigil'in Uslu'yu sanatoryuma sırası gelmeden başhekimin yardımıyla yatırması gösterilmekte; Uslu’nun sanatoryuma kabulü sırasında eşyalarını teslim etmesi, tartılması, göğüs 
röntgeninin çekilmesi ekrana getirilmekte; balkonda yarı çıplak erkek hastaların vücutlarına alkol sürülerek açık hava kürü uygulanmasına dikkat çekilmektedir. ${ }^{3,14}$

Film hastaların hüzünlü bir yalnızlık içinde bırakılmadıklarını, sosyalleşmelerini sağlayan aktivitelerin de gerçekleştirildiğini vurgulamakta; bunu izleyiciye kadın hastaların voleybol oynadığı, hastalara dönemin ünlü sanatçılarından Müşerref Hanım'ın konser verdiği sahneler üzerinden yapmaktadır. ${ }^{3,14}$ Ayrıca film, Heybeliada Sanatoryumu'nun önemli işlevlerinden biri olan rehabilitasyon etkinliklerine de dikkat çekmektedir. Bu bağlamda ön plana çıkan, iki genç şairin yazmaya olan tutkularını da dile getirdiği rehabilitasyon merkezindeki daktilo odası sahnesidir. ${ }^{3,14}$ Ancak burada filmin geçtiği dönem ile Heybeliada Sanatoryumu'nun tarihi arasında bir zamansal uyuşmazlık söz konusudur. Heybeliada Sanatoryumu'nun gelişim aşamasında özellikle kadınlara yönelik oküpasyon çalışmaları bulunmakla birlikte rehabilitasyon merkezi henüz açılmamıştır. ${ }^{15,17}$ Söz konusu rehabilitasyon merkezi, 1954 yılında faaliyete geçmiş; saat tamirciliği, stenodaktilografi, mulaj, fotoğrafçıık, saraçlık, elektrikçilik ve yağlı boyacılık eğitimi vermiştir. ${ }^{15,17}$

Sosyal, kültürel ve ekonomik zorluklarının yaşandığı erken cumhuriyet döneminin bu zor şartlarında ancak varsıl insanların sahip olabileceği standartları tüberküloz hastalarına sunan Heybeliada Sanatoryumu, çam ormanlarının içerisine yerleşmiş olağanüstü bir manzara ve iyi bakım hizmetleri ile özellikle başlangıç dönemindeki tüberküloz hastalarının tedavisinde başarılı olmuştur. ${ }^{15,17}$

Sağlık politikalarındaki değişim ile birlikte 1980'de sanatoryumun bütçesi azaltılmış, 17 Ağustos 1999 depreminde binaları hasar görmüş, i̇laç Endüstrisi İşverenler Sendikası'nın desteğiyle ancak 2001 yılında onarılabilmiştir. ${ }^{16,17}$ Bir yandan maddi imkansızlıklar öte yandan adaya deniz ulaşımının zor olması ve yeterli hasta olmaması gibi nedenlerin ileri sürülmesiyle 1 Ağustos 2005 tarihinde sanatoryumun hastaları, çalışanları ve tıbbi donanımı ile Süreyyapaşa Göğüs Kalp ve Damar Hastalıkları Eğitim ve Araştırma Hastanesi'ne devredilmesi kararlaştırılmışır. ${ }^{16,17}$ Sağlık hizmeti verdiği sırada önemli bir döneme de tanıklık eden Heybeliada Sanatoryumu'nun binaları 18 Ekim 2009'da çıkan yangında zarar görmüş, böylece bir tarih tamamen kapanmıştır. ${ }^{16,17}$

\section{Sonuç}

Kelebeğin Rüyası hem erken cumhuriyet döneminin sosyal, kültürel, politik yapısına özellikle salgın hastalıklarla mücadelesine ışık tutması hem de o döneme farklı bir perspektiften bakması açısından izlenmesi gereken bir filmdir. Önemli dönemlere tanıklık eden kurumların veya binaların kapatılması, zamana özgü ihtiyaçlar bağlamında kabul edilebilir hatta kaçınılmaz olsa da, bunlara ait kayıtların korunmamasını ve izlerin silinmesini, hem genel tarih hem de tıp tarihi açısından kayıp olarak değerlendirmek olanaklıdır. Heybeliada Sanatoryumu'nun kapatılmasının veya korunmamasının bu çerçevede büyük bir kayıp olduğu söylenebilir.

\section{Bilgi}

Bu makale, 2016-2017 akademik yılında Ankara Ü. Tıp Fakültesi Tıp Tarihi ve Etik Anabilim Dalında, Modern Tıp ve Cumhuriyet Tıp Tarihi doktora dersinde hazırlanan ödevler ve 15-18 Mayıs 2017 tarihinde Adana'da, X. Lokman Hekim Tıp Tarihi ve Folklorik Tıp Günleri'nde sunulan poster temel alınarak oluşturulmuştur.

Alper Bulut, makalenin tamamlanmasından sonra 5 Haziran 2019 tarihinde vefat etmiştir.

\section{Kaynaklar}

1. Babacan F, Hasdemir U. Mycobacterium Tuberculosis Kompleks. Editörler Willke Topçu A, Söyletir G, Doğanay M. Enfeksiyon Hastalıkları ve Mikrobiyolojisi Cilt 2. Üçüncü Baskı. İstanbul: Nobel Tıp Kitabevleri; 2008: 2283-4.

2. Kılıçaslan Z. Dünyada Tüberküloz Epidemiyolojisi. Editörler Yüce A, Özyurt M, Sürücüoğlu S, Uzun M, Sarıgüzel N. Mycobacterium tuberculosis ve Tüberküloz: Temel Bilimden KInik Tanı ve Tedaviye. İstanbul: ANKA; 2016: 1-9.

3. Kelebeğin Rüyası. Erişim tarihi: 11.10.2016, Erişim adresi: http://www.imdb.com/title/tt2608224/

4. Milli Müdafaa Mükellefiyeti Kanunu. Erişim tarihi: 10.10.2016, Erişim adresi:

https://www.tbmm.gov.tr/tutanaklar/KANUNLAR_KARARLAR/kanuntbmmc020/kanuntbmmc020/kanuntbmmc02003634.pdf.

5. Milli Korunma Kanunu. Erişim tarihi: 10.10.2016, Erişim adresi: http://www.resmigazete.gov.tr/arsiv/4417.pdf.

6. Lemlein RF. Influence of Tuberculosis on the Work of Visual Artists: Several Prominent Examples. Leonardo, 1981; $14(2): 114-117$.

7. Messer TM. Edvard Munch. New York: Harry N Abrams, 1985: 62. 
8. Chalke HD. The Impact of Tuberculosis on History, Literature and Art. Med Hist. 1962 Oct; 6(4): 301-318.

9. Çelik F. Edebiyatta Verem (Tüberküloz). Erişim tarihi: 14.10.2018, Erişim adresi: https://oggito.com/icerikler/edebiyatta-veremtuberkuloz/63321

10. Sona F. Divan Şairlerinin Gözünden Verem. Bilecik Şeyh Edebali Üniversitesi Sosyal Bilimler Dergisi 2017; 2(2): 610-618.

11. Pappas G, et al. Infectious Diseases in Cinema: Virus Hunters and Killer Microbes. Clin Infect Dis. 2003; 37(7): 939-42.

12. Thorley J. A voice for the silent. Lancet Respir Med 2016; 4(2): 100.

13. Çıraklı MZ, Yemez Ö. Yeşilçam Melodramlarında Veremli Kadın İmgesi ve Son Beste (1955) Filmi. Electron Turkish Stud. 2017; 12(34): 131-42.

14. Erdoğan Y. Kelebeğin Rüyası. İstanbul: Doğan Kitap, 2013.

15. Gökçe Ti. Heybeliada Sanatoryumu: Kuruluş ve Gelişimi 1924-1955. İstanbul: İsmail Akgün Matbaası, 1957.

16. Gürgan M, Ulus T. İstanbul Heybeliada Sanatoryumu. Sağlık Düşüncesi ve Tıp Kültürü Dergisi 2011; 18: 98-101.

17. Yıldırım N, Gürgan M. Türk Göğüs Hastalıkları Tarihi. Editör Metintaş M. İstanbul: Türk Toraks Derneği, 2012.

18. Saygı T. İngiliz Generali Townshend ve Türkler. Danışman Kayam HC. Doktora Tezi, İstanbul Üniversitesi Atatürk İlkeleri ve İnkılap Tarihi Enstitüsü, İstanbul, 2011. 